\title{
ДИЈАЛЕКАТСКЕ ЦРТЕ КАЗИВАЫА О НЕЧАСТВИМ СИЛАМА
}

\begin{abstract}
„Казивања о нечастивим силама” је збирка прича о необичним феноменима као што су вампири, ђаволи, караконџуле и сл. Збирка садржи 152 кратка демонолошка предања које је сакупио и објавио проф. др Радослав Раденковић. Ове приче потичу из 31 села са подручја неколико српских дијалеката: призренско-јужноморавског, сврљишко-заплањског, тимочко-лужничког, косовско-ресавског и прелазних говора према (и)јекавским. Језик ових прича је народни, дакле, дијалекатски обележен. У овом раду дата је дијалектолошка анализа текстова праћена ареаланим тумачењима порекла прича.
\end{abstract}

Кључне речи: српски језик, дијалекат, књижевност на дијалекту.

\section{1. Увод}

Казивања о нечастивим силама наслов је збирке прича које је објавио покојни Радослав Раденковић, редовни професор Филозофског факултета. Професор Раденковић се бавио народном књижевношћу, а као резултат једног дела истраживања у овој области, како самосталног, тако и у сарадњи са студентима, настала је збирка прича прикупљаних у народу са ширег подручја Србије, а највећим делом са југоистока. Ова књига садржи 152 кратке приче из 31 села. Иако је ова збирка пре свега етнографски документ, дијалектолошка анализа ће показати како она може бити и добар дијалектолошки извор, што се могло досад видети и у другим књижевним делима ствараним на дијалекту. ${ }^{3}$

Приликом дефинисања појма о књижевној врсти којој припадају овак-

\footnotetext{
${ }^{1}$ tatjana.trajkovic@filfak.ni.ac.rs

${ }^{2}$ Ово истраживање финансијски је подржало Министарство просвете, науке и технолошког развоја Републике Србије.

Рад је настао у оквиру пројекта Српски језик некад и сад: лингвистичка истраживаға (бр. 360/1-16-10-01), Филозофски факултет Универзитета у Нишу.

${ }^{3}$ Тако је Асим Пецо показао како је Стеван Сремац био не само велики књижевник већ и вредан дијалектолог (Пецо, 1995). Наравно, бројни су аутори који су се такође бавили анализом књижевног текста писаног на дијалекту: Јордана Марковић, Радивоје Младеновић, Софија Милорадовић, Радмила Жугић, Радоје Симић, Драгана Радовановић, Голуб Јашовић, Видан Николић, Александар Милановић, Милка Николић, Јелена Јовановић Симић, Јаворка Маринковић, Драгана Томић и др.
} 
ве усмене творевине, познаваоци народног стваралаштва нису имали лак посао. Доминантни термин који се користи у литератури јесте демонолошко предање (Милошевић-Ђорђевић, 1978: 235). Вук Караџић је овај усмени облик сврстао у књигу Живот и обичаји народа српскога, где се разликују три групе предања: „вјеровање ствари којијех нема”, „постање гдјекојијех ствари” и ,јунаци и коњи њихови” (Караџић, 1987: 14-15). Према тзв. европској класификацији, прва група, „вјеровање у ствари којијех нема”, могла би се назвати митолошка и демонолошка предања (Стули, 1975: 121). ${ }^{4}$

Полазећи од става Б. Сикимић (2002), на примеру дела Стевана Сремца, и С. Милорадовић (2008), на примеру Петријиног венца Драгослава Михаиловића, да нека књижевна дела писана на дијалекту могу послужити и као етнографски извор, фолклорно сведочанство једног краја презентовано на народски начин, изворним народним говором, из угла дијалектолога могло би се кренути са ставом да један етнографски извор може послужити као материјал за дијалектолошка истраживања. У том смислу појам етнодијалекатски текст (Сикимић, 2002: 30) у потпуности испуњава обе своје функције. Иако су ове „приче о нечастивим силама” примарно сведочанстава о народним веровањима, оне су донеле бројна дијалекатска обележја крајева у којима су записане. Дакле, у овом раду ће се, пратећи интересанте приповести о чудним појавама и догађајима, издвајати језички елементи којима се показује дијалекатска особеност испричаног.

Циљ овог рада јесте утврђивање дијалекатских црта у појединачним казивањима. С обзиром на то да приче потичу из различитих крајева, најпре би требало размотрити ареално порекло забележених прича. Из тог угла, ситуација изгледа овако:

- По једна прича записана је у следећим селима: Мерџелат, Давидовац (код Сврљига), Жапско (код Врања), Чагровац, Ново Село (код Беле Паланке), Лалинац, Грбавче, Клисура, Галибабинац, Кална, Околиште;

- По две приче записане су у селима: Копајкошара, Чокот (код Ниша), Извор;

- По три приче записане су у местима: Ниш, Кравље, Малошиште;

- Четири приче записане су у селу Орљану;

- Пет прича долази из Булатовца (код Прокупља);

- По шест прича је из Прве Кутине и Гулијана;

- Седам прича је из Зубетинца;

- По осам прича је записано у селима Плужина и Каре;

- По десет прича је из Витановца (код Краљева) и Бежишта;

- Једанаест прича је записано у Поточићу (код Прокупља);

- Тринаест прича је из Орешца;

\footnotetext{
${ }^{4}$ Дугујем захвалност проф. др Данијели Поповић Николић која ми је дала корисне смернице и савете у терминолошком прецизирању.
} 
- Деветнаест прича је записано у Речици (код Житорађе).

Највећи број места и прича које потичу одатле испричане су на неком од дијалеката призренско-тимочке дијалекатске области. Пре самих детаљнијих анализа могло би се претпоставити да су казивања из 11 места са подручја С3 дијалекта, приче из 9 села су на ПЈ дијалекту, а из 4 села су казивања са терена на ТЛ дијалекта. Са КР подручја или подручја које је дијалекатски прелазно према ПЈ долазе приче из 4 села. Са подручја које је дијалекатски прелазно према ХК испричане су приче из два села.

Да ли су ове претпоставке тачне најбоље могу потврдити дијалекатске одлике самих прича које потичу из поменутих села. Битније дијалекатске црте показаће о ком дијалекту или дијалекатском типу се ради, те ће се у том правцу вршити дијалектолошка анализа текстова из ове збирке народних прича. Међутим, показало се да се у једном казивању нађу одлике два различита дијалекта, што може указивати на две могућности: да је казивач досељеник са подручја неког другог дијалекта или да се ради о месту које је на граници два дијалекта. ${ }^{5}$

\section{2. Дијалекатска обележја предања са подручја призренско-тимочких говора}

\section{1. Опита призренско-тимочка обележја.}

У низу усмених приповедања које потичу од казивача пореклом из неког од села призренско-тимочке дијалекатске области могу се препознати опште одлике ових говора. За анализу је одабрано 55 прича записаних у местима из овог краја. Опште карактеристике ПТ говора препознају се у следећим примерима груписаним према дијалектолошким категоријама специфичним за ову област.

2.1.1. Полугласник је у текстовима ретко бележен на посебан начин. Најчешће се среће вокал $a$ на месту очекиваног полугласника. Тамо где је

\footnotetext{
${ }^{5}$ Анализа се ослања на следећу дијалектолошку литературу: Ивић, 1985, Ивић, 2009, Окука, 2017. У неким случајевима дат је осврт на садржаје у појединим монографијама које описују говоре са ширег подручја одакле потичу предања: Богдановић 1979, Богдановић 1987, Ћирић 1983, Ћирић 1999, Марковић 2000, Милосављевић 2009, Вукадиновић 1996, као и на дијалекатске речнике: Митровић 1984, Златановић 1998, Жугић 2005, Динић 2008, Стојановић 2010. Неке монографије управо се односе на контакт два дијалекта. Тако Богдановић (1979) пореди С3 и ТЛ тип (Богдановић 1979). Монографија Станислава Станковића (2008) самим својим насловом (Границе призренско-тимочких говора у власотиначкоме крају) указује на односе и диференцирање сва три призренско-тимочка дијалекта на једном малом подручју. Марина Јуришић (2009) је описала говор Горње Пчиње у коме се уочавају две зоне, једна блиска јужноморавском типу, а друга лужничком, које су се развиле на крајњем југу, где је и био могућ додир ова два дијалекта.
} 
посебно означен, користи се апостроф или нема никаквог посебног знака за овај глас иако је очигледно да се ради о полугласнику.

он је $m$ ’ имал $(10)^{6}$; зачс се напраји гомилка (18), па га рчну (18).

2.1.2. Екавска замена јата у одричном облику глагола јесам забележена је у следећим примерима:

несам могао (8), још несам ноћувал (26), несам видела (113), више несам ишла (25);

неси знала (2), неси упамтија (11), неси туј (21); неје пушка пуцала (1), неје знаја (6), он тој неје знаја (6), док га неје обалила (6), неје му се спало (10), тој неје без ништа (10), неје била млого стара (14), неје могла да израсте (17), ал му неје могла ништа (20), неје ошашавила (22), неје лажа (122), неје се одма сетила (124), неје смел да га отвори (138); да се несу одвезале (5), деца несу имали (6), несу косили (17), несу ништа (17), дом неје ни доодил (17), али га несу пробадали (19), несу таг имали трактори (24), затој несу смели (115), више несу стањували (148) итд.

2.1.3. Финално л чува се у свим призренско-тимочким говорима код именица, придева и прилога сем у радном глаголском придеву мушког рода једнине, где се у призренско-јужноморавском налази -(j)a.

петал се огласи (111); коњ бел (122), он гол од мајку (113), цеел дан (15), цุел ноћ (124); одоздол зафрљачи (7), окол воденицу (21) итд.

2.1.4. Сугласник $x$ се најчешће губи, али има и примера супституције другим сугласнком. Овакво стање потврђују и примери из ових прича.

оћеш и куде оћеш (9), како оћу (24), оће да гу возим (125), oће да гу возим (125); заладило (8), како питије (8), заманул сас бритву (9), почне да преоди (15), почне да преоди (15), дом неје ни доодил (17), саранили га (19), проодили кроз Стублину (115), доодил вампир (138), тија домаћини нетејали (140), доодил вампир (138); диго се једанпут (14), ја се ослободи (14), ја ману очи (14), кад се ја уплаши (14) и сл.

по мејане (9) и сл.

2.1.5. Сугласничка група -cm у финалној позицији се упрошћава у -с и такви примери нашли су се у испитиваној грађи:

да покрије крс (7), крс да ти не виде (12), не виде крс (25), да ни не види крс (122) и сл.

2.1.6. Африкатизација је забележена у примерима:

ударише пцеета (10), пџеета навалише (10), ока и пџује (14) и сл.

\footnotetext{
${ }^{6}$ Број у загради представља редни број казивања под којим се оно налази у самој збирци. Редослед примера дат је према редном броју приче.

${ }^{7}$ Облици су пренети онако како су записани у збирци.
} 


\subsection{7. Заменички облиции и енклитике препознати су у:}

да ни не види крс (122), да ви кажем (9), ћу ви дадем (21), пред юи (9), юојан син (139) и сл.

2.1.8. Употреба повратне заменице $c$ јавља се у:

само си ме бог спасил (14), пошал си дом (16), ама сам си редовно прекађувал врата (26), он си знал (140) и сл.

2.1.9. Партикуле су бројне како у показним заменицама, тако у прилозима:

кој знаје кво је мислеја (12), кој ти знаје (14), кој знаје који је (140); овој ћу испричам (13), овој се истински десило (15), овија бре Донинци (6); на туј страну (2), баш myj јесен умреја (7), maj баба (8), myj ноћ (14), moj е змеј (2), тој нема (5), на тој место (8), саг тој нема (9), тој се знаје (11), тој проклетија (18), какво је тој (24), не траја тој млого (26), тија људи (9), тија домаћини нетејали (140), теј осење (9), теј руке (19); онај жена (14), онуј другу (2), онеј искре (18), нема никој по сокак (25);

седе туj (21), mуj куде реку (24), туј умрела нека жена (121), myj имала срећу (124), такој (4), ја такој (8), такој бива (8), ете затој (1) и сл.

2.1.10. Аналитичка деклинащија уочава се у бројним примерима:

од стоку чували (6), дрво испод кубе (7), из кубе (7), кад се вртал из воденииу (9), до Цареву бару (9), врћали од пазар (12), до Коритарски поток (13), испало из кола (13), он рипнул из черге (15), дошли до реку (15), главу од коња (21), куде сливјанске појате (22), из Гојмановции смо пошли (23), код Ветрило се мени принуждило (23), до Габровачку реку (24), туј куде реку (24), од косидбу (25), кад смо ишле од Општину (114), она је от Мајмунции (114);

рекла на брата (140); на њега па причал (21),

татко води волови (24);

ама се помешал сас кишу (7), сас зуби (8), заманул сас бритву (9), сас острушку (10), сас сено (11), сас комшију (15), сас Немщи и сас Бугари (15), са своје очи (18), сас стоку (18), с једну руку (19), сас торбиче (21), сас жешку ракију (21), сас купус (24), сас глогов колаи (138);

гледамо по обор (5), живели у воденииу (6), оно зачури по собу (7), пасем овце по рудину (8), по градину (14), на Божинову појату почели да поју (15), седели на вреће (21), по врбаци (21), седим на кола (22), нема никој по сокак (25), нешто перу у корубу (25), кад бил баш на окуку (123) итд.

2.1.11. Вокатив на -е код именица ж. р. на -ка забележен је код антропонима Милка: Милке, ооо, мори, Милке (124).

2.1.12. Аналитичка компарација препознаје се у:

најчисту (4), пођавол од вас (5), појако да лају (10), једну поголему и једну помалу тестију (25), ама све послабо, послабо (26), па све појако 
(26), имал помладу сестру (140) и сл.

2.1.13. Футур I исказан конструкцијом енклитика $+(\partial a)+$ презент забележен је у следећим случајевима:

ће сврнемо (2) овој ћу испричам (13), ће појде (13), све ћу испричам (14), ће напрајиш нешто (14), спремија ће диде (20), ћу ви дадем (21), ће идемо на свадбу (23), кво ће работи (124), па ћу поминем (125), ће дидемо (152) итд.

2.1.14. Употреба аориста и илперфекта се потврђује примерима: диго се једанпут (14), ја се ослободи (14), ја ману очи (14), кад се ја уплаши (14), почеше сабирају (18), падо и потроши обе тестије (25), не траја тој млого (26), бео некако забаил се (125), чим паднеше први мрак (126) и сл.

2.1.15. Глаголи на -ујем имају аналошко -y- у инфинитивној основи као што је у облицима:

питували ји сватови (9), вода за навођување (14), па ме питује (14), кога да питујеш (18), ама сам си редовно прекађувал врата (26), кад смо га закопували (132) и сл.

2.1.16. Проширени глаголски облици срећу се у примерима:

тој се знаје (11), кој знаје кво је мислеја (12), кој ти знаје (14) и сл.

2.1.17. Грађење учесталих глагола као у потврдама:

провејује снег (7), само жутеје (18).

2.1.18. Специфично грађење глаголских облика видно је у облицима: немој да дизаш реп (26), почела да бега (141).

2.1.19. Творбу деминутивних облика уз помоћ суфикса -че показују примери:

да продадемо кравче (12), загрнул гуњче (17), по једно каменче (21), по једно кондирче (21).

2.1.20. Удвајање објекта потврђено је мањим бројем примера:

Дима га нема (16), нема гу девојка (125).

2.1.21. Трагове старе синтетичке деклинације у дативу именица и заменица женског рода или у неким прилозима потврђени су облицима:

па вели баба Насти (7), кад какво се њему десило (9), мислеја да је некоме испало (13), кад било јутром (17), било ноћум (19), седели туј ноћум (21), пошал да ради ноћу (123), вечером иде на воду (139), ноћум расфрљило (150) и сл.

У списку диференцијалних особина три типа власотиначког говора Станковић наводи и дативски облик са екавским рефлексом у наставку (сеcmpe) с разликом да се овакви облици срећу у ЗГ и ЛГ, док се у ЈГ налази 
само аналитичка форма (на сестру) (Станковић, 2008: 79). Постојећа грађа из збирке предања није дала повода за овакво упоређивање.

2.1.22. Лексика која је карактеристична за дијалекте призренско-тимочког подручја већ је потврђена бројним дијалекатским речницима (Митровић 1984, Златановић 1998, Жугић 2005, Динић 2008, Стојановић 2010 и др.), а у предањима која су анализирана налазе се бројни примери:

како укопан (2), куде је се денула (4), там куде бунар (7), куде мене (8), caz ћу ја (9), куде ми живимо (9), саг тој нема (9), како ветар (10), у овој добо (11), малецко кутре (12), мава реп (12), ич нема (14), ока и пцује (14), топрв таг видел (15), голема навалица (16), мука га накарала (16), укачила се на кола (16), големо оро (17), игра оро (17), големо како гувно (17), оно лази (18), и умоча га (18), улезне у тестију (18), да умоча, да угалати (18), да кладе огањ (19), куде уши (20) гоиа људи (21), наклали огањ (21), улегла девојка (21), сас жешку ракију (21), куче се згрчило (21), куде сливјанске појате (22), код Ветрило се мени принуждило (23), не могу му разбијем спање (24), какво је тој (24), туј куде реку (24), куде једног човека (24), да прокарамо кола (24), гоиа време (25), нема никој по сокак (25), море погледа (25), нешто перу у корубу (25), зуби како палци (25), падо и потроши обе тестије (25), немој да работиш (25), кво ће работи (124), врташем се ја (125), моје гуњче (125), па ћу поминем (125), оно запоја петле (125), куде је (125), куче суботьак (126), кад сам ја била малечка (126), куде њојан гроб (126), умеје сас њега (137), малко понатам (139) и сл.

2.2. Обележја која се примарно могу приписати призренско-јужноморавском дијалекту препознају се у следећим примерима.

2.2.1. Најбројнији су примери радног глаголског придева мушког рода једнине на $-(j) a$ :

отишаја у шталу (5), искочија из шталу (5), застануја (5), татко се таг сетија (5), он тој неје знаја (6), узеја клас (6), он се чапљискаја (6), неје знаја какво праји (6), мој брат је бија суботар (7), он је све могаја (7), па видеја и тога (7), баш туј јесен умреја (7), одокле је домаја (7), оно се тај Милун бија увампирија (7), и до сад си радија (11), неси доодија (11), неси упамтија (11), деда одназад заспаја (12), татко је водија краве (12), деда се возија (12), а он узеја капу (12), окренуја наопако (12), деда се спремија (13), водија волови (13), он први видеја (13), познаја (13), његов брат потрчаја (13), мислеја да је некоме испало (13), деда га уватија (13), спремија ће диде (20), имаја пешке (20), неје ништа имаја (20), кад дошаја (20), он се уплашија (20), искривија капу (20), и такој ищаја (20), такој се спасија (20), кад ми је татко бија жив (24), деда се успаја (24), овај га познаја (24), рекаја он (24), скрија се (136) он се скинаја (136), он ву рекја (136), он дошја (136), некој што се по- 
вампирија (137), ишаја мој деда (148), кад дошаја (148), викаја деда по њи (148), деда знаја (148), него се врнуја (148), он повикаја (148), како изговорија (148), кад улегаја (149) итд.

2.2.2. У нешто мањем броју потврђена су друге карактеристичне одлике ПЈ дијалекта као што је рефлекс лу вокалног л, заменица њума, суфикс -ики за грађење множине именица средњег рода, презент 3. л. мн. на -в, лексема татко.

слунце климнуло (8);

до ғума (7), сас краци на ғума (124);

кад гу видев (12), морав сви да једев (136), причав људи (137);

очи како соларчики (124), кучики почну да ржу (126);

татко се таг сетија (5), татко је водија краве (12), мој татко (20), татко ништа (22), татко отрча (24).

У Бучуму и Белом Потоку налазе се облици презента 3. л. мн. углавном на -y, али и на -e (Богдановић, 1979: 79). Говор Алексиначког Поморавља има форме на -в, али и на -y (Богдановић 1987: 184). Заплањски говор је обележен „шаренилом облика” (Марковић 2000: 165) и јављају се наставци $-e,-y$ (са честим уопштавањима овог наставка) и -в, при чему се последњи наставак везује за зону II, која представља мешавину С3 и ПЈ (Марковић 165). Станковић налази да код сва три типа говора власотиначког краја нема разлике у облицима презента 3. л. множине, те се тако и у ЈГ не среће презент на -в (Станковић, 2008:72). У говору Црне Траве и Власине доминирају наставци на -y (Вукадиновић 1996: 206-207). За разлику од овог, у пчињском говору у обема зонама (чак и оној источној) употребљава се презент јужноморавске форме на -в (Јуришић 2009: 203-204).

2.2.3. Један пример показује најјужнију карактеристику призренско-јужноморавских говора где у глаголским облицима долази до нж > на:

он се скинаја (136).

\section{3. Сврљичко-заплањска и тимочко-лужничка обележја.}

С обзиром на то да се ради о дијалектима који, поред разликовних, имају и заједничке одлике, овде ће бити издвојени примери које бисмо могли, ако их узимамо у обзир потпуно изоловано од осталог контекста, приписати било ком од ова два дијалекта.

2.3.1. Нејотовани лабијали у збирним именицама везују се пре свега за C3 и ТЛ говоре, мада се понегде могу чути и у неким ПЈ.

у шупља дрвја (1), везувале смо снопје (2), до гробје (12), иза гробје (12), однесу на гробје (126).

Исту ситуацију налазимо у говорима Бучума и Белог Потока (Богдановић, 1979: 39), Заплања (Марковић, 2000: 85), Црне Траве и Власине (Вукадиновић, 1996: 111-112), као и у говору Пчиње (Јуришић 2009: 99). 
2.3.2. Најбројније потврде односе се на употребу финалног л у радном глаголском придеву мушког рода једнине:

неје смел да пројде (1), пошал дом (1), омркал у воденицу (1), јамал коња (1), коњ почел да ржи (1), помислел (1), слегал од кљусе (1), узел јаренце (1), почел да га милује (1), Милан се убездерил (1), врљил јаре (1), обол коња (1), утекал у Преконогу (1), ставнил у воденицу (1), морал да си иде (1), замолил воденичара (1), коњ станул (1), све се ущвикал (1), коњ се опрајил (1), донел човека (1), који је бил заман (2), бил на границу (3), там је служсил (3), бог јој дал добро (3), неје карал да појде (4), муж се дигал (4), туј ју уванул (4), ама се помемал сас кишу (7), деда Стојан причал (9), кад се вртал из воденицу (9), заманул сас бритву (9), мен причал мој деда Драга (10), он је т'г имал (10), ја сам баш поодил (10), седел он увечер (10), грејал се (10), бил сам ји стурил (10), Жутов дошал (10), а тенац се завукал (10), само си ме бог спасил (14), договорил се (15), он легал и заспал (15), ), излегал на лесу (15), грабнул срп (15), па пошал (15), како је спал (15), окнул низ сокак (15), трчал (15), неје могал да ји стигне (15), дошал на сред (15), оно се брв почел љуља (15), Сима падал у реку (15), све се окупал и укаљал (15), врнул се дом (15), не могал одмори (15), овој ми је причал (16), како е причал (16), он потерал мливо (16), кад стигал там (16), морал да чека (16), пропуштил жито (16), пошал си дом (16), па се сетил (16), умотал се (16), он ћутал (16), спашакал се у врећу (16), таг сврљил покравац (16), погледал у вола (16), уванул волови (16), он чувал овце (17), там спал (17), дом неје ни доодил (17), и чул (17), послушал боље (17), чудил се (17), загрнул гуњче (17), узел тољагу па пошал (17), прегазил реку (17), гледал тој чудо (17), подигал овце (17), па окнул (19), турал дрва (19), на њега па причал (21), Стеван окнул (21), башта је водил краве (22), ушиљил шубару (22), једанпут окнул (24), па га питал (24), зачудил се (24), што сам ја доживел (26), и такој зајебавал људи (111), бил утенчил (111), там се растурил (113), накачил дреје (113), бил на стражу (113), он се просвестил (113), док пројду (115), како је све патил (116), он омркал (117), кад се вртал (117), више неје смел (117), прејде им мачка пут (118), почел да га мами (119), онак савил рози (121), там тропал (121), загрмел коњ бел (122), па растршил гриву (122), па прогрмел (122), пошал да ради ноћу (123), кад бил баш на окуку (123), деда развртел лампу (123), пошал Тика (123), отишал на гробје (133), наклал огањ (138), легал да спије (138), трал коњи (139), настајил пут (140), пожурил коња (140), ишл, ишл, ишл и чул (143), радел он тако (144), он само нестал (144), чича имал девет деца (152), кад се врнул, погледал (152), човек отишал за леб (152) итд.

Финално $л$ је једна од веома важних црта која дели говор Заплања на две зоне: у првој се у радном глаголском придеву м. р. јд. оно чува, а у другој 
се може заменити са -(j) $a$ (Марковић 2000: 81-82). Станковић наводи ову фонетску одлику као диференцијалност између испитиваних ЛГ и ЗГ, на једној страни, и ЈГ, на другој (Станковић 2008: 78 и карта 8). У пчињском говору на целом простору је у употреби -ja у радном глаголском придеву и нема ниједне потврде за -л у овој категорији (Јуришић 2009: 97).

2.3.3. Бројни су примери облика у којима није извршено специјално јотовање што је општа одлика С3 и ТЛ говора.

дојдомо до раките (2), после си дојде (3), дојде свења (7), пројде и тој чудо (7), појдо там (8), да пројде тај (9), појдо да узнем кандило (10), ће појде (13), и ја појдем (23), појдомо још малко (24), не мож да пројдемо (24), чекамо свекра да дојде (25), оно ми дојде свења (25), не мож да се најдеш (25), дојде један ован до врата (121), кад пројде (122), кад се вампир најде на муку (138), како појду (152) итд.

Овај фонетски дијалектизам налази се и код Станковића као значајна разлика између ЛГ и ЗГ према ЈГ у власотиначком крају (Станковић, 2008: 78 и карта 11). Подељеност на источни и западни део пчињског говора јасна је и према употреби нејотоване или јотоване групе јд (Јуришић 2009: 100).

2.3.4. Неки облици заменичких енклитика који се употребљавају на подручју С3 и ТЛ говора веома ретко се могу чути или их уопште нема у ПЈ крајевима. Употреба појединих заменичких облика може представљати основ за дифернцијацију суседних говора који се налазе на прелазу два дијалекта. Тако Тања Милосављевић налази да облици заменица 3. л. јд. ж. p. „представљају једну од главних дивергентних црта у говорима ова два села [Горњи Присјан и Доњи Присјан]" (Милосављевић 2009: 478), те на основу присуства енклитика $j y$ и $y$ у Горњем Присјану и $j y, y$ и гу у Доњем Присјану, закључује да се у првом случају ради о лужничком говорном типу, а у другом о заплањском (Милосављевић, 2009: 478-479). Исто важи за плуралске заменичке облике. У заплањском типу (Доњи Присјан) користи се $z u, u$, а у лужничком типу (Горњи Присјан) само ји (Милосављевић 2009: 480). Енклитику 3. л. јд. женског рода јо налазимо у бележењима Недељка Богдановића у говорима Бучума и Белог Потока (Богдановић 1979: 67), али и у Алексиначком Поморављу где аутор наводи да „би се шаренило могло схватити као мешање више система заменичких облика и њихово планирање" (Богдановић 1987: 165). Енклитике јо нема у Лужници (Ћирић 1983: 72), у Понишављу (Ћирић 1999: 130), у Заплању (Марковић 2000: 141-146), у Црној Трави и Власини (143-144). На основу овога може се закључити да се забележени примери са јо могу односити на сврљишки тип С3 говора. У Алексиначком Поморављу Богдановић није забележио енклитике $у$ (али $y$ је присутно мада не често, што важи за облик гу), вој и плуралску енклитику $j u$ (али $u$ је забележено, мада као веома ретка појава, за разлику од ги које је опште обележје) (Богдановић 1987: 167-168). Енклитике jy, вој и ји налазе се у говорима Бучума и Белог Потока (Богдановић 1979: 67), Понишавља 
(Ћирић 1999: 130, 131, 133), Лужнице (Ћирић 1983: 73), Заплања (Марковић 2000: 143-144, 146), Црне Траве и Власине (Вукадиновић 1996: 150, 162). Интересантно је да о стању оваквих заменичких облика нема потврда код Станковића, који наводи разликовне форме ғу и ғума (Станковић, 2008: 71, 79). Јуришић не бележи заменице $j o, j y, в о j, ~ j u$, те се може рећи да су у целини пчињског говора заступљени типични јужноморавски облици (Јуришић 2009: 142-149).

па јо се придремало (4), тој шашавило јо се разишло (4), туј јо топло (10), дно јо се не види (24), ја јо таг исприча (25),

туј $j y$ уванул (4),

па вој рекла (139), да вој дадем (125),

да $j u$ кекењишу (1), терале $j u$ (1), некад $j u$ имало (9), неје могал да $j u$ стигне (15), како ји видо (25), ништа $и$ неје омитало (118),

2.3.5. Упита заменица какво / кво карактеристика је С3 и ТЛ говора за разлику од ПЈ где се користи шта. Овакве тврдње налазимо код Богдановића (1987: 170) с тим да се „у крајњим источним селима зоне II и III уместо што / шта може чути: какво, како је иначе у сврљишким говорима" (Богдановић $1987: 171)$. Чешћу употребу облика какво, кво уочили су и Марковић 2000: 148, Богдановић 1979: 68, Вукадиновић 1996: 154-155, Ћирић 1983: 75, Ћирић 1999: 137. На додиру јужноморавског и лужничког у пчињском говору преовладава упитна заменице што мада су забележени ретки примери које и какво са истом функцијом (Јуришић 2009: 151).

исприча какво је било (5), какво се њему десило (9), какво окам (10), некакво га приокало (15), кво све праје (25), кво буде (139).

2.3.5. Суфикс -ики се користи за грађење множинских облика именица средњег рода у ПЈ говорима (Белић 1905: 366), те би се примери са -ићи могли односити на С3 и ТЛ (в. Богдановић 1979: 56, Марковић 2000: 124, Милосављевић 2009: 469). Међутим, у неким јужноморавским говорима може се срести суфикс -ићи (Богдановић 1987: 150, Станковић, 2008: 79), те следеће примере не треба узимати као одлучујуће у одређивању дијалекатске припадности.

кравчићи (5), кондирчићи (21), лају кучићи (21), погледа на тестичићи (25).

2.3.6. Иако лексика не би требало да представља основ у постављању дистинкција између дијалеката, постоје очигледни примери које не можемо игнорисати и уопштавати њихово простирање. О диференцијалној улози лексике у призренско-тимочким говорима на тлу власотиначког краја пише Станислав Станковић, који, након ширег историјског, географског и културолошког осврта, истиче значај одређених лексема у повлачењу неких изоглоса на овом подручју: „наиме, многе забележене лексеме и њихове семеме јесу заједничке или су пак само донекле присутне у двама, првенствено у лужничкоме и у заплањскоме, па чак и у свима трима месним говорним типо- 
вима, али је осећај својине, одн. припадности одређене речи веома различит, па је тиме и сама њена употреба, посебно у јужноморавскоме говору, често врло ограничена и специфична, тј. лингвостилистичка" (Станковић 2008: 74). Као изразити пример, Станковић наводи лексему бәшта „која припада основноме лексичком фонду ЛГ и ЗГ" додајући да се она у јужноморавским говорима „чује спорадично, претежито при наглашавању диференцијације или какве карактеризације носилаца лужничкога или заплањскога говорног типа" (Станковић 2008: 74). Примарно везивање одређених лексема за С3, ТЛ или ПЈ свакако се може потврдити увидом у постојеће дијалекатске речнике: Динић 2008: 22, 518; Стојановић, 2010: 53, 917, Жугић, 2005: 385). Из испитиване грађе издвојила сам следеће примере, који се пре свега односе на СЗ и ТЛ говоре:

његов башта (21), ставнимо ја и башта (22), башта је водил краве (22); нешто окнуло (1), та ме окаш (4), нека жена приокала (4), а ја таг кад окну (10), какво окаш (10), он окну (12), не окај (14), ја окну (25), ока и пцује (14) и сл.

2.4. Одређени број примери могао би се приписати и ПЈ и С3 јер садрже елементе који нису сасвим карактеристични за ТЛ дијалекат. Ово се пре свега односи на рефлекс вокалног $\pi$, групе * $t j$, * $d j$ и лужничку палатализацију. Исте фонетске одлике са истим односом наводи и Станковић као основ за диференцирање три типа говора (Станковић, 2008: 68, 78). Богдановић у Бучуму бележи нпр. млаиеј, меиа, а у Белом Потоку млађеј, међа (Богдановић, 1979: 38).

у вуну (136);

$\hbar е$ сврнемо (2), у сред ноћ (4), ће ми напрајите ред (21), ћy ви дадем (21), и покрил све до веђе (131), на туђа врата (121), ово је било баш пред Божић (124), туј имала срећу (124), ће јо даде (139), ћу дидем ће му извадимо душу (146);

сваки дан (3), девојке замицале (15), девојке све у белетине (17), улегла девојка (21), сас жешку ракију (21), тај девојка (21), нема ракија (21), неки човек из Глоговац (111), три руке мавају (19), таг се премниле у девојке (117), код туј девојку (117).

2.5. Нека казивања садрже комбинацију таквих елемената који говоре о упливу стандардног језика до чега је могло доћи из различитих разлога. Један од узрока присуства стандардних облика може бити начин приступа приповедачу који сам комбинује идиоме. Такав случај је приповедање под бројем 11 из села Чагровца у којем је казивач користио стандардну варијанту српског језика у улози приповедача, али је у дијалозима које је преносио употребио дијалекат: 
„Дао ја гас до даске, а точкови пиште, зарибало све, опет гас, аја-ништа! Сиђем ја с мотора, дајем гас и гурам, опет ништа, да макне, све се укочило! [...] Стигнем кући у неко доба, скоро ће зора, а жена вели: „,Мито бре, кој ти је белај? И до сада си радија у ту смену па неси доодија у овој добо!”

2.6. Постоје неки примери који сведоче о интересантној комбинацији ПJ, с једне стране, и С3 / ТЛ црта, с друге стране, те се може претпоставити да се ради о говорима који су на ареалном прелазу:

кој знаје кво је мислеја (12), кад дојдев до гробје (136).

2.7. Примери који указују на то да је текст највероватније записан на С3 подручју:

Милан с у врећу скочанил (1), засија како сланце (2), какво оћеш (4), легал између натлаче чешире (5), сваки се уванул (9), она девојка (12), иди там па виђ кво је чудо (14), он рипнул из черге (15), вреће (16), још несам ноћувал (26), ама сам си редовно прекађувал врата (26), оћал ђавол (26), натлакал ју до уши (112), да ће до њег да стигну (117), ишал с неки људи (118), скинул се с коња (140).

2.8. Одлике на основу којих се засигурно може закључити да прича долази са подручја ТЛ дијалекта јесу лужничка палатализација, појава $\iota, \mu<* t j$, *dj и чланска морфема, по којима је и Станковић утврдио изофоне на власотиначком говорном подручју (Станковић, 2008: 78, 80, карте 9, 10, 20). Палатализивање $\kappa$, 2 , африкате $ч$, $\mu$ од $* t j$, *dj карактеристике су говора Бучума, не и Белог Потока, док се употреба члана налази у оба говора (Богдановић, 1979: 41-42, 39, 74-76). Говор Црне Траве и Власине дели се на две зоне према ч, $u<* t j$, *dj, умекшање $\kappa$ и 2 је потпуно у првој зони (тимочко-лужничкој), а спорадично у другој (сврљишко-заплањској), што је случај и са употребом чланске морфеме (Вукадиновић 1996: 96). У пчињском говору је у употреби члан, али доста редуковано на крајњем западу; нема лужничких одлика увези са сугласницима $\kappa$, г и $m$, $\partial$ (Јуришић 2009: 189, 90, 91). У говору Заплања Јордана Марковић, поред облика са $\hbar, \hbar$, бележи и примере са $\iota, \mu$; нема потврда за лужничку палатализацију (Марковић, 2000: 77-80, 87).

друђо неје тел да једе (133), била се превукла нека сенћа (139), овај сенћа се као измакнула (139), гледала се баба и сенћа (139), и сенћа гледала бабу (139), нека сенћа (139), а сенћа пририпила (139), сенћа ујаши (139), некакве девојће (140), гле онеј девојће (140), у село на седењћy (141), љуће се изгубе (143), држи у руће (143), и тој пешће (146); чу отворим (139), једанпут ночу чула се свирка (145);

кудето је бил одар (7), мачката ни осењила (118), само снајуту стискала за гушу (134), мојата матер (140), а јарето по њу (141), остајил cac dememo (152). 
2.9. Свеобухватном анализом текстова требало би узети у обзир како контекст тако и ареал, који нам аутор / приређивач нуди. Повезивањем и укрштањем свих чиниоца моможе се доћи до закључака о ком дијалекту или о каквој дијалектаској прелазности се ради.

\section{3. Дијалекатска обележја предања са подручја косовско-ресавског дијалекта}

3.1. Косовско-ресавска обележја очекивала су се код 15 прича, за које ce, према географском одређењу, може претпоставити да припадају овом дијалекту. Ипак, показало се да има доста елемената дијалекатске прелазности.

3.2. Поточић и Булатовац налазе се у непосредној близини Прокупља, на самој граници између КР и ПЈ о чему сведоче и примери из прича записаних у овим селима. Најбројније су потврде аналитичке деклинације, која се као балканизам све више преноси из призренско-тимочких говора.

између Пашинац и булатовачку црку (85), неки костур од главу (85), из Булатовац (86), до поток (87), преко поток (87), с ону страну (87), из воденииу (88), дођем до мост (88), близу Булатовач (89), код булатовачку цркву (89), стигнем до поток (95), све тако до поток (97), до окуку (97), поред јаз (98);

ишла према реку (87);

терао коњи (89), избуљило велики очи (96);

па озгор засипали с поројину (85), остали с бабу (86), пођем с бабу (86), с кола (86), с краве (86), с празна кола (86), кола натоварена сас дрва (88), његова мајка с мене (88), сас коюска кола (89), са заову (89), сас Немизи (95), сас клашье (98);

стоји на руке (85), само у доюи веш (85), била сам у Рељеинац (87), био сам у планину (88), муж ми је био у милицију (89), био је у Кочане (89) и сл.

Али и: после причам баби (87), до заласка сунцуа (88), да видиш ове моје краве (88), човеку преврнули кола (88), зајебавају људе (88), рекоше мојему свекру (89), рекла мом оиу (91), ја сам причала мојему стрицу (99), витлају кондирима (99) и сл.

3.3. Вокатив на -е: снајке (89), као и облик именице тате: тате, ел чујеш (91).

\section{4. Облици заменичких енклитика:}

омајали не (86), па не обрнули (86), врате не назад (86), целу ноћ не водили (86), људи не питују (86), куде су ни дрва (86), шта гу је (91), ja 
све ги гледам (99) и сл.

3.5. Употреба партикула и неизвршено јотовање групе јд упућује на могућност миграција које су овакве црте донеле у овај крај:

сумљам у тија ђаволи (92), по теја распутишта (89);

дојдомо до Ровине (93), пројдем ја (95).

3.6. Радни глаголски придев м. р. јд. јужноморавског лика препознаје се у примерима:

почеа да га милује (94), пошеа да потовари бурићи (94).

Међутим, у истом тексту постоје и форме: потоварио бурићи (94), узео га на крило (94).

Иначе, највећи број примера радног глаголског придева је на -о:

нисам се поздравио (85), нити сам се прекрстио (85), чим се свекар зауставио (89), чим је повукао дрво (89), лежао сам (90), кад сам пошао у Куршумлију (92), ишао сам с коњем (92), кад сам дошао до Ровине (92), одједаред скочио коњ (92), муњевито трчао (92), тако се зауставио (92), дотерао коњ (92), кад сам био војник (95), ништа нисам говорио (95), за њим отишао (95), само сам видео лице (95), како сам подвикнуо (95), ћутећи сам ишао (95), неје имао ко други (88), домао неки човек (98), кад сам носио клашње (98), ја сам морао назад (98), ја сам се расвестио (98), нисам знао (98).

3.7. Ту је и пример јужноморавског презента на -в: како да вучев (88). Има и потврда уопштавања наставка -y код презента 3. л. множине које добро познају не само ПТ говори, већ и КР:

да се краве зноју (88), да се кола кочу (88).

3.8. Одричан облик глагола јесам најчешће је икавске форме:

није било кутре (97), нисам се више окретала (96), нисам се поздравио (85), где ме нису све водили (85), није дете (89), ниси ти возила та кола (88), док његова мајка није дошла (88), нисам могао да устанем (90), нисам смео да идем ноћу сам (91) и сл.

Међутим, нашли су се неки примери са екавским рефлексом јата: несам знала (88), неје имао ко други (88), неје имао никакв човек (93).

3.9. Прилошки облик куде, који је карактеристичн за ПТ говоре, нашао се и у причи са КР подручја: куде идеш (98).

3.10. Неки примери потврђују губљење сугласника $x$ : ја те тедо средим (87), сад ме било стра (97).

3.11. Има појединачних случајева, углавном фонетских и лексичких, 
који се могу везати како за ПТ тако и за неке КР говоре:

сретьа свадба (85), толко су мокре (88), позади мене (87), млого нападају на коње (92).

3.12. Један пример показује типичну косовско-ресавску форму ки: бега ки зинзара (93).

\section{4. Предања са подручја прелазних говора са елементима (и)јекавских говора ${ }^{8}$}

4.1. Витановац је село код Краљева (како је сам аутор / приређивач навео), што би највероватније значило да ове приче носе одлике западнијих типова КР дијалекта. ${ }^{9}$

\footnotetext{
${ }^{8}$ Ивић тумачи појаву, природу, порекло и простирање ијекавско-екавских говора, као и појаве екавско-ијекавских мешавина у западним подручјима Србије (Ивић, 2009: 52-62). Детаљно проучавајући границе ијекавских говора у западној Србији, Славољуб Марковић наводи типове говора овог подручја: ијекавски говори са мањим бројем екавизама, ијекавски говори са знатним бројем екавизама (ијекавско-екавски), слободна ијекавско-екавска мешавина, екавски говори са знатним бројем ијекавизама (екавско-ијекавски), екавски говори са знатним бројем икавизама (екавско-икавски), екавски говори, говори са ẹ/e < в (Марковић, 2012: 413, 420, 435, 438, 440, 441, 454, 457). О „екавско-јекавском развитку” говора делова западне Србије писао је и Игрутин Стевовић (Стевовић, 1969: 435, 436). О „нетипичним К-Р говорима екавско-ијекавског типа" у доњем сливу Студенице пише Гордана Драгина у монографији Говори у сливу Студенице (Драгин, 2015: 209). Драгана Радовановић, у оквиру испитивања говора Ваљевске Подговрине, истиче ареал ијекавско-екавских и екавизираних ијекавских говора (Радовановић, 2014: 92-93).

${ }^{9}$ Увидом у постојеће дијалектолошке монографије о говорима ових крајева западне Србије који захватају ближа подручја око Краљева није пронађено село Витановац као саставни део ареала истраживања дијалектолога. Игрутин Стевовић (1969: 410, 411) своја испитивања заснивао је на говору родног села Борач, које је се налази на око 38 км северно од Краљева и наводи да је гружански говор најтипичнији у свом централном делу коме припадају села: Борач, Претоке, Бумбарево Брдо, Гунцати, Кнић, Рашковићи, Драгушица, Брњица, Забојница, Гривац, Опланићи, Топоница, Кусовац, Бечевица, Брестовац, Бело Поље (Стевовић, 1969: 411), што је област којој не припада Витановац (који се налази доста јужније од њих).

Радоје Симић је за потребе описивања говора суседног Левча испитивао говор следећих села: Баре, Беочиће, Богалнице, Велика Крушевица, Вукмановац, Горњи Дубич, Горња Сабанта, Доброселица, Драгово, Дубрава, Дулене, Жупањевац, Кавадар, Калинички Прњавор, Калудра, Карановац, Комаране, Крчин, Леповиће, Ломница, Лоћике, Малешево, Мотриће, Надрље, Опариће, Превеш, Ратковиће, Ребеновац, Рековац, Секурич, Сибница, Сиљевица, Слатине, Сугубине, Течиће, Урсуле, Цикоте, Шљивица (Симић 1972: 29, 30). Ова места се налазе североисточно и источно од Витановца.

Гордана Драгин је за испитивање говора доњег слива Студенице (не узимам у обзир горњи слив јер се тамо ради о северозападном делу ових студеничких говора зетско-сјеничког типа), који припадају специфичном екавско-ијекавском типу косовско-ресавског дијалекта, посетила места: Саово, Палеж, Ђаково, Брезова, Засад, Прћане, Косурићи, Камењани, Каменска и Никољача (Драгин, 2015: 18, 209). Сва ова места налазе се неколико десетина километара
} 
У њему је записано 10 прича о нечастивим силама. За разлику од свих претходних примера, овде се наилази на инфинитив, што је једна од најбитнијих разлика међу овим дијалектима. Такође, синтетичка деклинација је заступљена и нема потврда аналитизма.

4.1.2. Потврде синтетичке деклинације:

испод огромног старог ораха (107), није чинио никаква зла (109);

sуде је попустио страх (106);

посипају брашном (104), додирујући је ногама (105), није тео с юим да разговара (105), отуда нас гађа шљьвама (109), неке сличности $c$ вукодлаком (109);

нашла је Миладина на прагу куће (103), што се у водениции нашло (104), више никад није у воденищи заноћио сам (104), да зврши посао у Карановиу (108), на врху главе (110), у правиу потока (110) итд.

\subsection{3. Иако су ретки, постоје примери употребе инфинитива:}

ко да прошишти (101), нечастиви се оће изгубити (101), волови су били испрегнути (102), било је страшно видети га и чути (109).

4.1.4. Неки случајеви показују да се у овом говору уопштава наставак -y у презенту 3. л. множине:

југозападно од Витановца. Моравички говори које је истраживао Владан Николић обухватају пунктове који се налазе на око стотинак километара западно од Витановца (Николић, 2001). С друге стране налази се говор Александровачке жупе (Марковић, 2014), чији су пунктови такође удаљени десетине километара али југоисточно од Витановца и који припада централном косовско-ресавском типу (Марковић 2014: 35).

У монографији Трстенички говор Душан Јовић наводи места које је посетио: Велика Дренова, Медвеђа, Мијајловац, Богдање, Стопања, Тоболац, Велуће, Ратаје, Шљивово, Стубал, Чукојевац, Подунавци, Врба, Грачац (Јовић, 1968: 3). Од наведених трстеничких места једна група припада тзв. III зони: Чукојевац, Стубал, Врба, Подунавци, Грачац, а ради се о говорном типу који се пружа „од Врњачке Бање према Краљеву са обе стране Мораве“ (Јовић 1968: 4). Јовић није посебно и подробно анализирао особености овог типа, већ се позивао на њих „онда када је било потребно подвући разлике и објаснити поједине проблеме трстеничког говора и његове повезаности са ширим подручјем" (Јовић, 1968: 3). Ова места су такорећи у непосредној близини села Витановца, те се тако Чукојевац налази на нешто мање од 4 километра источно од Витановца. Међутим, с друге стране, западне, на око петнаестак километара од Витановца започиње ареал који је испитивао Славољуб Марковић ради утврђивања граница ијекавских говора у западној Србији. Места у најближој западној околини Краљева према Марковићу припадају III сектору, где пролази „међа која србијански (и не само србијански) дијалекатски комплекс оштро пресеца на две изразито раздељене целине: на млађе (новоштокавске) и старије штокавске говоре“ (Марковић, 2012: 441). У вези са овом зоном, Марковић закључује да најисточнији део овог подручја, који је најближи ибарској долини и краљевачкој области ,запремају екавски говори косовско-ресавске базе”. Ако се све ово узме у обзир, могло би се рећи да је говор Витановца близак западном типу трстеничког говора, али и источном типу поменутог сектора III, те због тога у раду наводим да је говор овог села један од најзападнијих типова косовско-ресавких говора. Тако се могу објаснити поједини јекавски примери уз бројне екавске потврде. 
веселу се (100), стално праву свадбе (100), веселу се ко људи (100), да се почасту сас буклију (100).

4.1.5. Истовремена употреба јекавских и екавских ликова указује на то да се ради о прелазном говору, који се налази на граници између ова два изговора.

вуци те изјели (101), ћерао дрва (102);

оне девојке нема (102), угледао две девојке (104) имала је троје деце (107), најстарије дете (107), девојичи се одузеле и руке и ноге (108), нашли је премрзлу у снегу (108).

4.2. Казивања из села Каре указују на то да се ради о неком новоштокавском прелазном говору према ијекавским. Да је новоштокавски упућују облици новоштокавске деклинације, а да се ради о прелазном према ијекавским указују форме које су карактеристичне за (и)јекавске говоре: сажимање вокалске групе -ао у корист првог вокала (боја, прича), примери јекавског јотовања (Ђевојком, вође) са истовременим јављањем екавских ликова (није човек, него човечић (59), сила од човека (62), они човек (62)). Иначе, доступне мапе Србије не налазе село Каре на претпостављаном подручју ${ }^{10}$, те се једино може помислити да се ради о досељенику из јекавских крајева, по чему је позната околина Прокупља и Житорађе, ${ }^{11}$ где се налази село под именом Каре.

4.2.1. У наставку следе примери који потврђују јекавско јотовање, јекавске и икавске форме, сажимање $-a о>-a$, асимилацију $c$ у $u$, показну заменицу м. р. једнине ови, употребу конструкције предлог nym + генитив, употребу имперфекта, употребу приповедачког императива.

да зађевају сено (58), са ђевојком (60), има вође (62), све је шћело (63); а опанци му све исијепани (65), воду да се угрије (64);

па је $и$ юим искочио (59), шћаше да га удави (59), оженити $и$ юом (60), све чакрља и њим (64), целу ту ноћ је био и юима (65);

он негде отиша (58), није се ничега боја и ово је сам прича (62);

да ће се ови момак оженити ш њом (60), после се ови човек иселио (61), ови човек (64);

иде пут Госпавине куће (60), nут ње да је ухвати (60), гледају пут њега (64);

он мимльаше (60);

онда она пођи ка потоку (60), он пошаљи жену (58), пушти ти он (62), онда он вуции волове (62).

\footnotetext{
${ }^{10}$ https://www.google.com/maps/place/\%D0\%9A\%D0\%B0\%D1\%80\%D0\%B5/@43.0991206,21 $.5357538,10.66 \mathrm{z} / \mathrm{data}=! 4 \mathrm{~m} 5 ! 3 \mathrm{~m} 4 ! 1 \mathrm{~s} 0 \times 47559150 \mathrm{ce} 0 \mathrm{e} 8 \mathrm{~b} 63: 0 x e d 50869 \mathrm{a} 642 \mathrm{f} 6 \mathrm{e} 99 ! 8 \mathrm{~m} 2 ! 3 \mathrm{~d} 43.1072$ $669 ! 4 \mathrm{~d} 21.7286945$

11 https://www.pmf.ni.ac.rs/download/master/master_radovi_geografija/geografija_master_radovi/2016/201610-27-jm.pdf
} 


\section{5. Закључак}

Збирка предања под називом Казивања о нечастивим силама написана је дијалектом, али се ради о неколико различитих српских дијалеката или прелазних типова тих дијалеката. На једном месту нашли су се: три призренско-тимочка дијалекта, косовско-ресавски и два прелазна: екавско-јекавски и јекавско-екавски. У причама се могу наћи и елементи стандардног српског језика на местима где се то не би очекивало. Може се рећи да ове приче нуде богат извор дијалекатске грађе чијом се обрадом долази до закључака о изворним одликама неког дијалекта, о начинима утицаја стандардног језика, па и о ареалном везивању и тумачењу простирања датог дијалекатског типа. Иако аутор / приређивач даје значајне информације о информаторима, о месту записивања као и информације у виду аутентичних записа, чак ни после тога не би се могло са сигурношћу тврдити да су анализиране одлике текста уједно и одлике говора места одакле потичу записи. Овде је пре свега реч о тексту на дијалекту и о дијалекатским карактеристикама текста, јер се из само записаних речи не може знати какви су екстралингвистички чиниоци утицали на постојећу форму текста.

\section{Литература}

Богдановић, 1979: Богдановић, Недељко. Говори Бучума и Белог Потока, Српски дијалектолошки зборник XXV, Институт за српскохрватски језик, Београд, 1979, 1-179.

Богдановић, 1987: Богдановић, Недељко. Говор Алексиначког Поморавља, Cpnски дијалектолошки зборник XXXIII, Институт за српскохрватски језик, Београд, 1987, 7¥302.

Вукадиновић, 1996: Вукадиновић, Вилотије. Говор Црне Траве и Власине, Срnски дијалектолошки зборник XLII, Институт за српски језик САНУ, $9 \ddagger 317$.

Динић, 2008: Динић, Јакша. Тимочки дијалекатски речник, Институт за српски језик САНУ, Монографије 4, Београд.

Драгин, 2015: Драгин, Гордана. Говори у сливу Студенище, Нови Сад, Тиски цвет.

Жугић, 2005: Жугић, Радмила. Речник говора јабланичког краја, Српски дијалектолошки зборник LII, CAHУ, Институт за српски језик, Београд, $1 \neq 470$.

Златановић, 1998: Златановић, Момчило. Речник говора јужне Србије, Учитељски факултет, Врање.

Ивић, 1985: Ивић, Павле. Дијалектологија српскохрватског језика: Увод и штокавско наречје. Нови Сад: Матица српска, 1985.

Ивић, 2009: Ивић, Павле. Српски дијалекти и њихова класификаиија, Издавачка књижарница Зорана Стојановића, Нови Сад - Сремски Карловци, 2009.

Јовић, 1968: Јовић, Душан. Трстенички говор, Српски дијалектолошки зборник XVII, Институт за српскохрватски језик, Београд, 1968, $1 \neq 240$. 
Јуришић, 2009: Јуришић, Марина. Говор Горње Пчиње (гласови и облиии), Институт за српски језик САНУ, Монографије 6, Београд.

Караџић, 1987: Вук Стеф. Караџић. Живот и обичаји народа српскога. Дела Вука Караџића: Етнографски списи. О Црној Гори. Београд: Просвета, Београд: Нолит.

Марковић, 2000: Марковић, Јордана. Говор Заплања, Српски дијалектолошки зборник XLVII, CAHУ, Институт за српски језик, Београд, $7 \ddagger 307$.

Марковић, 2012: Марковић, Славољуб. Границе ијекавских говора у западној Србији, Српски дијалектолошки зборник LIX, САНУ, Институт за српски језик, Београд, $387 \ddagger 484$.

Марковић, 2014: Марковић, Милош. Говор Жупе александровачке, Друштво за српски језик, Београд.

Милосављевић, 2009: Милосављевић, Тања. Говор села Присјан (Доњи и Горњи), Српски дијалектолошки зборник, САНУ, Институт за српски језик, Београд, 2008, 383-558.

Милорадовић, 2008: Софија Милорадовић, Једно могуће читање Петријиног венца или књижевно дело као етнодијалекатски текст, Слике културе некад и сад, 60 година Етнографског института САНУ, Зборник 24, Етнографски институт САНУ, Београд. Институт за српски језик САНУ, 223-236.

Милошевић-Ђорђевић, 1978: Нада Милошевић Ђорђевић, Речник усмених књижевних родова и врста, Књижевна историја, Београд, 1978.

Митровић, 1984: Митровић, Бран. Речник лексовачког говора, Лесковац, Народни музеј.

Николић, 2001: Николић, Видан. Моравички и горњостуденички говори, Научно друштво за неговање и проучавање српског језика, Београд.

Окука, 2018: Окука, Милош. Српски дијалекти, Прометеј, Нови Сад, 2018.

Пецо, 1995: Асим Пецо, Стеван Сремац као дијалектолог, Јужнословенски филолог LI, Институт за српски језик САНУ, Београд, 247-265.

Радовановић, 2015: Радовановић, Драгана. Говор Ваљевске Подгорине, Српски дијалектолошки зборник LXI, CAHУ, Институт за српски језик Београд, $1-365$.

Сикимић, 2002: Биљана Сикимић, Фолклорни елементи у делу Стевана Сремца, Къижевно дело Стевана Сремия - ново читање. Зборник радова са научне конференције одржане у Нишу 15. и 16. новембра 1996. године, Центар за научна истраживања САНУ и Универзитета у Нишу, Студијска група за српски језик и књижевност Филозофског факултета, Ниш.

Симић, 1972: Симић, Радоје. Левачки говор, Српски дијалектолошки зборник XIX, Институт за српскохрватски језик, Београд, $1 \neq 618$.

Станковић, 2008: Станковић, Станислав. Гранище призренско-тимочких говора у власотиначком крају, САНУ, Институт за српски језик Монографије 5, Београд, 2008.

Стевовић, 1969: Стевовић, Игрутин. Шумадијски говор у Гружи са особитим 
освртом на акценте, Српски дијалектолошки зборник XVIII, Институт засрпскохрватски језик, 401-635.

Стојановић, 2010: Стојановић, Радосав. Црнотравски речник, Српски дијалектолошки зборник LVII, САНУ, Институт за српски језик, Београд.

Стули, 1975: M. B. Stulli; Narodna predaja - Volkssage - kamen spoticanja u podjeli vrsta usmene proze. U: Usmena književnost kao umjetnost riječi, Zagreb.

Ћирић, 1983: Ћирић, Љубисав. Говор Лужнице, Српски дијалектолошки зборник XXIX, САНУ, Институт за српскохрватски језик, Београд, 7-190.

Ћирић, 1999: Ћирић, Љубисав. Говори Понишавља, Српски дијалектолошки зборник XLVI, CAHУ, Институт за српски језик, Београд, 7 ₹262.

https://www.google.com/maps/place/\%D0\%9A\%D0\%B0\%D1\%80\%D0\%B5/@43.0 $991206,21.5357538,10.66 \mathrm{z} /$ data $=! 4 \mathrm{~m} 5 ! 3 \mathrm{~m} 4 ! 1 \mathrm{~s} 0 \times 47559150 \mathrm{ce} 0 \mathrm{e} 8 \mathrm{~b} 63: 0 x e d 5086$ 9a642f6e99!8m2!3d43.1072669!4d21.7286945 (Посећено: 20. 1. 2020)

https://www.pmf.ni.ac.rs/download/master/master_radovi_geografija/geografija master_radovi/2016/2016-10-27-jm.pdf (Посећено: 20. 1. 2020)

Tatjana G. Trajković

\title{
DIALECT CHARACTERISTICS OF ,KAZIVANJAO NEČASTIVIM SILAMA“"
}

\begin{abstract}
Summary
„Kazivanja o nečastivim silama“ is a collection of stories about unusual phenomens similar to vampires, devils, karakondzulas and etc. The book contains 152 short stories that were collected and published by Radoslav Radenković. These stories were collected in 31 villages on the territory of few serbian dialects: Prizren-South Morava, Svrljig-Zaplanje,Timok-Lužnica, Kosovo-Resavian, transitional speeches according to (i)yekavian. Language of stories is the language of folks speaker and is therefore marked with dialectical lines. This paper provides a dialectological analysis of the text. An explanation of the presence of specific dialectical elements and a closer areal interpretation of the origin of the stories is given.
\end{abstract}

Key words: Serbian language, dialect, literature written in dialect. 